\title{
Novel insights into the mechanisms of pregnancy establishment: regulation of prostaglandin synthesis and signaling in the pig
}

\author{
Agnieszka Waclawik \\ Institute of Animal Reproduction and Food Research of Polish Academy of Sciences, Tuwima 10, \\ 10-747 Olsztyn, Poland \\ Correspondence should be addressed to A Waclawik; Email: waclawik@pan.olsztyn.pl
}

\begin{abstract}
Ovarian progesterone induces essential changes leading to a temporary state of uterine receptivity for conceptus implantation. Estrogens secreted by the porcine conceptus on days 11 and 12 of pregnancy provide the initial signal for maternal recognition of pregnancy and maintenance of a functional corpus luteum $(C L)$ for continued production of progesterone. As prostaglandins $F_{2 \alpha}\left(P F_{2 \alpha}\right)$ and $E_{2}\left(P G E_{2}\right)$ exert opposing actions on the $\mathrm{CL}$, a tight control over their synthesis and secretion is critical either for the initiation of luteolysis or maintenance of pregnancy. One of the supportive mechanisms by which conceptus inhibits luteolysis is changing PG synthesis in favor of luteoprotective $\mathrm{PGE}_{2}$. Conceptus $\mathrm{PGE}_{2}$ could be amplified by $\mathrm{PGE}_{2}$ feedback loop in the endometrium. In pigs, as in other species, implantation and establishment of pregnancy is associated with upregulation of expression of proinflammatory factors, which include cytokines, growth factors, and lipid mediators. The conceptus produces inflammatory mediators: interferon $\gamma$ and interferon $\delta$, interleukins IL1B and IL6, and PGs, which probably activate inflammatory pathways in the endometrium. The endometrium responds to these embryonic signals by enhancing further progesterone-induced uterine receptivity. Understanding the mechanisms of pregnancy establishment is required for translational research to increase reproductive efficiencies and fertility in humans and animals.

Reproduction (2011) 142 389-399
\end{abstract}

\section{Introduction}

Species-specific variations in maternal recognition of pregnancy and implantation processes exist, and these differences preclude the formulation of unifying theories for the molecular basis of these events. This review addresses recognized signaling cascades and new research in mechanisms responsible for conceptusendometrial interactions during the peri-implantation period in the pig with some comparisons with other species.

Prostaglandins (PGs) play a pivotal role in luteolysis as well as in establishment of pregnancy (Bazer \& Thatcher 1977, McCracken et al. 1999, Waclawik et al. 2009a). Corpus luteum $(\mathrm{CL})$ regression on days $15-16$ of the estrous cycle results from an increase in pulsatile endometrial secretion of prostaglandin $\mathrm{F}_{2 \alpha}\left(\mathrm{PGF}_{2 \alpha}\right)$ in pigs (Moeljono et al. 1977). The porcine CL does not display a luteolytic response to exogenous $\mathrm{PGF}_{2 \alpha}$ until days $12-13$ of the estrous cycle. The insensitivity of the early CL to exogenous $\mathrm{PGF}_{2 \alpha}$ is caused partially by lower luteal $\mathrm{PGF}_{2 \alpha}$ receptor concentration on day 14 of pregnancy in comparison with the corresponding day of the estrous cycle and a deficiency in post - $\mathrm{PGF}_{2 \alpha}$ receptor signaling (Gadsby et al. 1993, Zorrilla et al. 2009).

The role of oxytocin (OXT) in controlling $\mathrm{PGF}_{2 \alpha}$ secretion is not as well defined in pigs as in ruminants
(Mirando et al. 1995, Waclawik et al. 2010). In ewes, luteal OXT acts through endometrial OXT receptors to generate a $\mathrm{PGF}_{2 \alpha}$ pulse which in turn stimulates further secretion of OXT as well as inducing functional regression of the $\mathrm{CL}$ through inhibiting progesterone synthesis (reviewed in Jenkin (1992)). In the pig, OXT may not be responsible for the initiation of luteolysis but is more likely involved in the control of pulsatile release of $\mathrm{PGF}_{2 \alpha}$, especially the height and frequency of the peaks of this hormone during luteolysis (Kotwica et al. 1999). Surprisingly, OXT concentration in the uterine lumen significantly increases on days 12-14 of pregnancy compared with the corresponding days of the estrous cycle (Vallet et al. 1998). Moreover, OXT is not luteolytic when administered locally to the uterine lumen as it is when administered systemically (Sample et al. 2000) and i.u. infusion of OXT decreases plasma concentrations of $\mathrm{PGF}_{2 \alpha}$ metabolite, PGFM, on day 16 after estrus (Sample et al. 2004). In addition, OXT stimulates synthesis and secretion of $\mathrm{PGE}_{2}$ (PG which has the opposite action to $\mathrm{PGF}_{2 \alpha}$ on the $\mathrm{CL}$ ) by endometrial luminal epithelial (LE) cells only during early pregnancy but not on the corresponding days of the estrous cycle (Waclawik et al. 2010). 


\section{Pregnancy recognition mechanisms}

Pregnancy establishment in mammals requires prolongation of luteal life span and progesterone production. Progesterone stimulates secretory functions of the endometrium required for conceptus development and implantation. The pregnancy recognition signals secreted by the conceptus may be luteotrophic, if they directly maintain $\mathrm{CL}$ function, or antiluteolytic, if they decrease uterine release of luteolytic $\mathrm{PGF}_{2 \alpha}$ (Auletta \& Flint 1988, Bazer et al. 2010).

Maternal recognition and establishment of pregnancy in pigs requires the biphasic pattern of estrogen secretion (Geisert et al. 1990). Conceptuses secrete increased levels of estrogens, mainly $17 \beta$-estradiol $\left(E_{2}\right)$, on days 11-12 and between days 15 and 25-30 of pregnancy. Maternal recognition of pregnancy occurs simultaneously with rapid transformation of trophoblast from spherical to tubular, and then filamentous forms between days 10 and 12 before implantation (Geisert et al. 1990). The observation that conceptus elongation has not been achieved in vitro indicate that this process may not be exclusively controlled by conceptus transcriptional changes and the uterine environment has a pivotal role in the initiation of trophectodermal remodeling in the pig (Ross et al. 2009).

Luteoprotective action of estrogen is complex. It stimulates luteal progesterone secretion directly (Conley \& Ford 1989). Indirect action of estrogen involves increasing luteal LH receptor concentration (Garverick et al. 1982), decreasing $\mathrm{PGF}_{2 \alpha}$ release from uterus into the peripherial circulation (Bazer \& Thatcher 1977), and regulating PG synthesis and signaling in the endometrium (Waclawik et al. 2009a) and conceptus (A Waclawik, unpublished observations). Estrogen receptor (ESR) expression in LE and glandular epithelium (GE) of the endometrium (Geisert et al. 1993) and in the conceptus (Kowalski et al. 2002) coincides with estrogen secretion from the conceptus, suggesting both autocrine and paracrine actions. On day 12 of pregnancy, ESR 1 mRNA abundance is elevated in the LE (Ross et al. 2010). Both a sufficient amount of conceptus estrogen synthesis and timing of the endometrial exposure to estrogen is crucial for establishment of pregnancy. Premature administration of estrogen on days 9-10 of pregnancy results in embryonic loss by day 15 and altered endometrial expression of many genes (including PG-endoperoxide synthase 2; PTGS2), probably causing desynchronization of the uterine environment and conceptus implantation (Geisert et al. 2006).

Estrogen has both systemic and local effects in the maternal system (Ford et al. 1982). It is likely that the local effect of estrogen on the endometrium is limited to regions in close proximity to the conceptus due to metabolic activity of trophectoderm. During pregnancy, the endometrium rapidly metabolizes $E_{2}$ to estrone sulfate, which is the biologically inactive form and is present in greater amounts in the uterine lumen of pregnant pigs (Flood 1974). Sulfatase enzyme activity of the trophectoderm restores the biological activity of estrogen that results in a localized effect of estrogen to regulate expression of some endometrial genes (Johnson et al. 2009, Waclawik et al. 2009a).

\section{Prostaglandins}

\section{Role of PGs during pregnancy establishment}

A tight control over PG synthesis and secretion is critical either for the initiation of luteolysis or maintenance of pregnancy in domestic animals (Kennedy et al. 2007). Reduced PG synthesis in the human endometrium may lead to poor endometrial receptivity for embryo implantation since PG synthesis appears to be disrupted in women with repeated IVF failure (Achache et al. 2010). It was demonstrated that inhibition of PG synthesis causes pregnancy failure before the implantation process in animals with different types of placentation, beginning from non-invasive placenta in the pig (Kraeling et al. 1985) and in ruminants (Erdem \& Guzeloglu 2010, Dorniak et al. 2011) to invasive placenta in rodents (reviewed in Kennedy et al. (2007)). Interestingly, blocking of PG synthesis does not affect elongation of trophoblast in pigs (Geisert et al. 1986).

Moeljono et al. (1977) demonstrated a decrease in peak amplitude and concentration of $\mathrm{PGF}_{2 \alpha}$ in the uteroovarian vein in pregnant gilts compared with cyclic pigs. However, another group reported that this difference in $\mathrm{PGF}_{2 \alpha}$ concentration in the ovarian-uterine vein is much less between cyclic and pregnant animals (Hunter \& Poyser 1982). Our results indicate that the content of PGF synthase (PGFS) mRNA and/or protein in the conceptus and endometrium is decreased in the first day of maternal recognition of pregnancy, between days 10 and 13 compared with later stages of pregnancy (Waclawik et al. 2006). However, after day 14 of pregnancy, content of PGFS mRNA and protein increases in both the endometrium and conceptus (Waclawik et al. 2006, Waclawik \& Ziecik 2007). Moreover, uterine flushings of pregnant pigs contain higher amounts of $\mathrm{PGF}_{2 \alpha}$ than those from cyclic animals (Zavy et al. 1980). It is likely that this upregulation of conceptus and endometrial PGFS resulting in an increase of $\mathrm{PGF}_{2 \alpha}$ in the uterine lumen during implantation could be involved in angiogenesis because $\mathrm{PGF}_{2 \alpha}$ signaling mediates expression of angiogenic genes (Sales et al. 2005). Nevertheless, the action of $\mathrm{PGF}_{2 \alpha}$ in this period should be restricted only to the uterus and conceptus. Therefore, to avoid luteolytic action of $\mathrm{PGF}_{2 \alpha}$ on the CL in ovary, $\mathrm{PGF}_{2 \alpha}$ is sequestered in the uterus probably by redirection of $\mathrm{PGF}_{2 \alpha}$ secretion from the uterine venous drainage (endocrine) to the uterine lumen (exocrine) by conceptus estrogen (Bazer \& Thatcher 1977). In addition, an antiluteolytic mechanism could involve 
the retrograde transfer of $\mathrm{PGF}_{2 \alpha}$ from the venous blood and uterine lymph into the uterine lumen and ability of uterine veins and arterial walls to accumulate $\mathrm{PGF}_{2 \alpha}$ (Krzymowski \& Stefanczyk-Krzymowska 2004).

Another potential mechanism by which the conceptus contributes to prevention of luteolysis is by changing PG synthesis in favor of the luteoprotective $\mathrm{PGE}_{2}$. The conceptus and endometrium synthesize increased amounts of $\mathrm{PGE}_{2}$ before implantation (Waclawik et al. 2006, Waclawik \& Ziecik 2007). A greater $P G_{2}: P P_{2 \alpha}$ ratio stimulates progesterone and $E_{2}$ secretion by luteal cells collected on days 10-12 of the estrous cycle (Gregoraszczuk \& Michas 1999). I.u. infusion of $\mathrm{PGE}_{2}$ delays the decline in plasma progesterone concentrations that normally occurs around day 15 and extends the luteal function in cyclic gilts (Akinlosotu et al. 1986). Greater $\mathrm{PGE}_{2}$ secretion in the gravid uterine horn of unilaterally pregnant pigs is associated with increased luteal weights and progesterone concentrations of ipsilateral CLs (Christenson et al. 1994). The infusion of $\mathrm{PGE}_{2}$ into the ovarian artery elevates the concentration of progesterone in the ovarian venous blood on days 13 and 14 of pregnancy (Stefanczyk-Krzymowska et al. 2006).

It should be emphasized that the conceptus and endometrial $\mathrm{PGE}_{2}$ secretion, similarly to embryo estrogen secretion, increases and begins to exert the luteoprotective action before days 14-15 of pregnancy (which in cycling gilts corresponds to initiation of luteolysis). In contrast to the pattern of PG secretion exhibited by nonpregnant gilts, pregnant animals have an earlier (days 11-13) transient rise in $\mathrm{PGE}_{2}$ and $\mathrm{PGF}_{2 \alpha}$ measured in the utero-ovarian venous plasma, during which $\mathrm{PGE}_{2}$ is the predominant uterine PG secreted (Christenson et al. 1994). Moreover, in unilateral pregnancy $\mathrm{PGE}_{2}$ concentrations in the utero-ovarian venous blood draining the gravid uterine horn are greater than in the non-gravid uterine horn, whereas $\mathrm{PGF}_{2 \alpha}$ concentrations do not differ between these two horns (Christenson et al. 1994). A local and systemic effect of $E_{2}$ on luteal progesterone secretion was observed in cyclic gilts receiving $E_{2}$ unilaterally into an isolated uterine horn on days 11-15 (Ford et al. 1982). The local effect of $E_{2}$ in stimulating progesterone production by ipsilateral ovary is not due to reduced $\mathrm{PGF}_{2 \alpha}$ concentrations in the uteroovarian blood draining the $E_{2}$-injected horn. Wasielak et al. (2008) indicated that in unilateral pregnancy on days $12-14$, there is more $\mathrm{PGE}_{2}$ in $\mathrm{CLs}$ ipsilateral to the gravid uterine horn compared with CLs from ovary adjacent to the non-gravid horn. This $\mathrm{PGE}_{2}$ probably originates from the conceptus and endometrium but not from the $\mathrm{CL}$ (Waclawik et al. 2008a). The conceptus $\mathrm{PGE}_{2}$ signal could be amplified by $\mathrm{PGE}_{2}$ feedback loop only in the gravid horn because of its local regulation (Waclawik et al. 2009a).

$\mathrm{PGE}_{2}$, after reaching the ovaries, may act through luteal PGE 2 receptors (PTGER), PTGER2 and PTGER4 (Waclawik et al. 2010). Other subtypes of PTGER have not been studied in the $\mathrm{CL}$ in this species yet. PTGER2 and PTGER4 are coupled to adenylate cyclase and generate CAMP that in turn activates the protein kinase $\mathrm{A}$ signaling pathway. $\mathrm{PGE}_{2}$ stimulates luteal progesterone secretion through a cAMP-mediated pathway in the CL in humans (Hahlin et al. 1988, Harris et al. 2001), rabbits (Boiti et al. 2000), and ruminants (Fitz et al. 1984, Weems et al. 2006). Moreover, the luteoprotective action of $\mathrm{PGE}_{2}$ may be mediated by elevated content of vascular endothelial growth factor (VEGFA) in the luteal cells on days 10-12 of pregnancy (Kowalczyk et al. 2008). In addition, downregulation of strong endogenous antagonist of this growth factor, its soluble receptor, on day 12 of pregnancy increases amount of available VEGFA (Kaczmarek et al. 2009). Increased content of VEGFA in the CL may maintain progesterone production by increasing luteal capillary permeability, which facilitates transport of PGs from the circulation and delivery of cholesterol to the luteal cells.

\section{Enzymes involved in PG synthesis during early pregnancy}

$\mathrm{PGE}_{2}$ and $\mathrm{PGF}_{2 \alpha}$ are synthesized by PTGS and specific terminal PG synthases: PGE synthase and PGFS. PGFS is considered to have both activities of $\mathrm{PGH}$ 9,11-endoperoxidase (reduction of the 9-,11-endoperoxide group of $\mathrm{PGH}_{2}$ to two hydroxyl groups of $\mathrm{PGF}_{2 \alpha}$ ) and PGD 11-ketoreductase (reduction of the $\mathrm{PGD}_{2} 11-$ keto group to $9 \alpha-, 11 \beta-\mathrm{PGF}_{2} ;$ Watanabe 2002). Moreover, $\mathrm{PGE}_{2}$ can be converted into $\mathrm{PGF}_{2 \alpha}$ by $\mathrm{PG}$ 9-ketoreductase/carbonyl reductase (CBR1). It was demonstrated that highly inducible forms of PTGS and PGE synthase in the porcine endometrium are PTGS2 (also known as PGHS-2 or COX-2; Ashworth et al. 2006) and microsomal PGE synthase-1 (mPGES-1), respectively (Waclawik et al. 2006).

Endometrial mPGES-1 expression exhibits a biphasic profile, corresponding with the profile of conceptus estrogen secretion (Waclawik et al. 2006). Our recent results indicate that estrogen elevates $\mathrm{PGE}_{2}$ synthesis and the $\mathrm{PGE}_{2}: \mathrm{PGF}_{2 \alpha}$ ratio by an increase of expression enzymes involved in $\mathrm{PGE}_{2}$ synthesis (PTGS2 and mPGES-1) and a decrease in the content of enzymes involved in $\mathrm{PGF}_{2 \alpha}$ production (PGFS and CBR1) in the endometrium on days 11-12 after estrus (Waclawik et al. 2009a). Accordingly, mPGES-1 expression is relatively high, whereas PGFS and CBR1 low in the endometrium between days 10 and 13 of pregnancy compared with the implantation period (Waclawik et al. 2006, Waclawik \& Ziecik 2007). Similarly, but more pronounced alterations of expression of enzymes involved in PG synthesis were detected in the conceptus. A $\mathrm{PGE}_{2}$ autoamplification loop can additionally contribute to the increase of the $\mathrm{PGE}_{2}: \mathrm{PGF}_{2 \alpha}$ ratio in the endometrium during the peri-implantation window (Waclawik et al. 2009a). $\mathrm{PGE}_{2}$ acting through endometrial PTGER2 receptor, 
activates cAMP signaling pathway and elevates the mRNA and protein expression of enzymes involved in $\mathrm{PGE}_{2}$ synthesis (PTGS2 and mPGES-1) and secretion of this PG by the endometrium (Waclawik et al. 2009a; Fig. 1). This finding is consistent with the reports that $\mathrm{PGE}_{2}$ itself may induce its own secretion in other cell types (Weems et al. 1999, Jabbour et al. 2001, Sales et al. 2001). Besides PTGER2, presence of PTGER4 in the porcine endometrium has been demonstrated (Waclawik et al. 2009a, 2009b) but receptors PTGER1 and PTGER3 have not been studied in this tissue.

\section{The uterine receptivity and implantation period}

In pigs, implantation occurs from days 14 to 19 of pregnancy. Uterine LE cells and conceptus trophectoderm are involved in an adhesion cascade within a restricted time of the estrous/reproductive cycle defined as the window of the uterine receptivity. This state is induced by progesterone from the ovary and may be further enhanced by additional factors secreted by embryo (Burghardt et al. 2002). The hallmark of the uterine receptivity window for conceptus implantation in many species is a loss of progesterone receptors (PGR) from LE and GE as result of sustained stimulation of the endometrium by progesterone. In pigs, loss of PGR occurs by day 10 of the estrous cycle and pregnancy (Geisert et al. 2006, Mathew et al. 2011). However, PGR are maintained in stroma and myometrium. Therefore, the effects of ovarian progesterone on expression of many factors in LE may be mediated indirectly either by progesterone-induced progestamedins produced by PGR-positive stromal cells or by induction of molecules in LE that causes downregulation of PGR to regulate expression of endometrial genes (Geisert et al. 2006, $\mathrm{Ka}$ et al. 2007). Downregulation of PGR in LE and GE coincides with activation of nuclear factor kappa $B$ (NFKB); however, a role of this transcription factor in inhibition of PGR expression was not confirmed in the pig (Ross et al. 2010, Mathew et al. 2011). NFKB activation is an important component in opening the implantation window in pigs and is probably involved in the increase in endometrial PTGS2 expression on day 12 after estrus (Geisert et al. 2006).

Loss of PGR from LE and GE induced by progesterone results in the decrease in mucin-1 from the apical surface of uterine LE and exposure of integrins for trophoblast attachment (Bowen et al. 1996). Pigs have a true epitheliochorial placenta in which LE remains intact throughout pregnancy. It has been suggested that mucin4 expressed in LE and in the superficial deep GE of the endometrium plays a role in protecting the surface epithelium from invasion (Ferrell et al. 2003, Østrup et al. 2010). Mucin-4 expression is significantly greater in the pregnant compared with the nonpregnant endometrium and may be responsible for modulating the proteolytic activity of the porcine conceptus (Ferrell et al. 2003). On the contrary, in an invasive

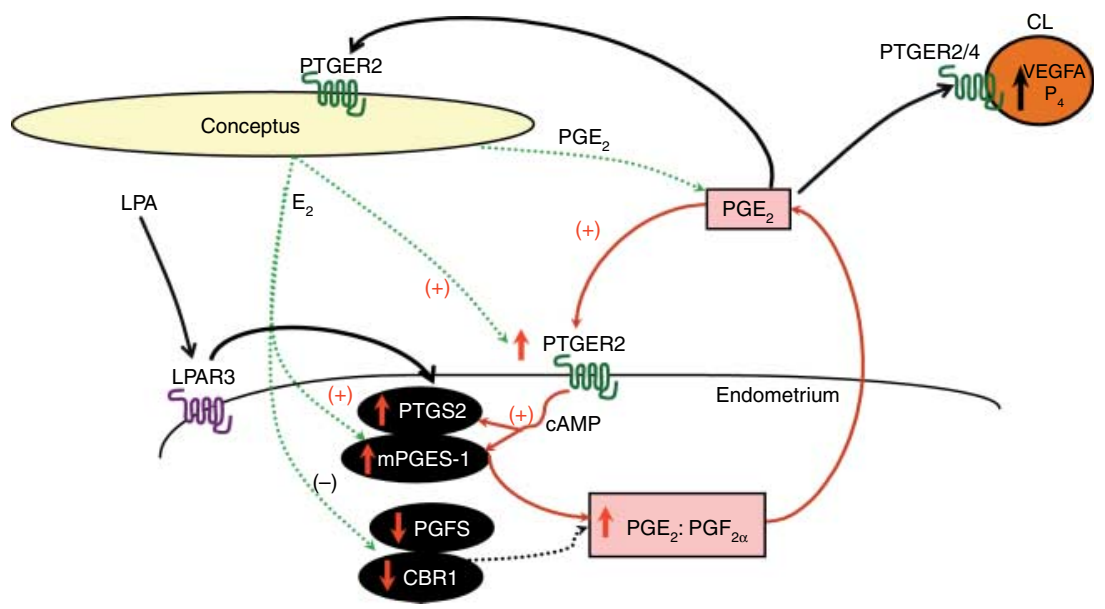

Figure 1 Proposed mechanism involved in increasing luteoprotective prostaglandin $E_{2}\left(P_{E_{2}}\right)$ level and the $\mathrm{PGE}_{2}: \mathrm{PGF}_{2 \alpha}$ ratio by a $P G E_{2}$ positive feedback loop during the period of the maternal recognition of pregnancy in the pig. The primary conceptus-derived factor, $17 \beta$-estradiol $\left(E_{2}\right)$, and another conceptus factor $\mathrm{PGE}_{2}$ regulate the protein expression of endometrial PG synthesis pathway enzymes to favor production of luteoprotective $\mathrm{PGE}_{2}$. $\mathrm{E}_{2}$ upregulates prostaglandin-endoperoxide synthase 2 (PTGS2) and PGE synthase (mPGES-1) protein expression and downregulates endometrial PGF synthase (PGFS) and prostaglandin 9-ketoreductase/carbonyl reductase (CBR1) protein concentrations increasing $\mathrm{PGE}_{2}$ secretion and the $\mathrm{PGE}_{2}: \mathrm{PGF}_{2 \alpha}$ ratio. $\mathrm{PGE}_{2}$ acts through endometrial $\mathrm{PGE}_{2}$ receptor (PTGER2), activates CAMP signaling pathway and elevates the mRNA and protein expression of enzymes involved in PGE $_{2}$ synthesis (PTGS2 and mPGES-1) and its own secretion in the endometrium. In addition, lysophosphatidic acid (LPA) present in the uterus may contribute to prostaglandin synthesis pathway by elevation of PTGS2 expression via its receptor (LPAR3). LPAR3 is upregulated by estrogen during the maternal recognition of pregnancy. Increased content of PGE $_{2}$ in the uterine lumen could directly promote uterine function and conceptus development. Expression of PTGER2 is upregulated on days 11-12 of pregnancy and was shown to be involved in a $\mathrm{PGE}_{2}$ positive feedback loop during the period of the maternal recognition of pregnancy. $\mathrm{PGE}_{2}$ originating from the conceptus and endometrium, after reaching the ovaries, may act through luteal PGE $_{2}$ receptors (PTGER2 and PTGER4) stimulating vascular endothelial growth factor (VEGFA) and progesterone secretion ( $\mathrm{P}_{4}$; modified from Waclawik et al. (2009a)). 
placentation type as in rodents, mucins are downregulated just before the implantation of the blastocyst (McNeer et al. 1998). Transforming growth factor $\beta$ (TGFB1) stimulates expression of extracellular matrix molecules (fibronectin - 'trophoblastic glue') and integrins, as well as proteases and protease inhibitors to facilitate conceptus-uterus connections during implantation and to limit trophoblast invasiveness (Burghardt et al. 2002, Jaeger et al. 2005).

Attachment of trophoblast to LE is facilitated by interactions between integrins and extracellular matrix proteins. Expression of $\alpha 4, \alpha 5, \beta 1$ integrin subunits increases in LE between days 11 and 15 in both cyclic and pregnant gilts and is regulated by progesterone alone, or together with estrogen (Bowen et al. 1996). Conceptus estrogen induces expression of secreted phosphoprotein 1 (SPP1/osteopontin) in LE during the apposition phase of implantation (White et al. 2005). SPP1 binds to integrins on trophoblast and LE resulting in activation of integrin receptors and cytoskeletal proteins to form focal adhesions in trophoblast cells (Erikson et al. 2009). In trophoblast cells, SPP1 acts through its Arg-Gly-Asp (RGD) sequence to bind $\alpha v \beta 3$ and $\alpha 5 \beta 1$ integrin heterodimers and to induce focal adhesions, as well as MTOR, p38, and ERK1/2 signaling pathways to affect cell adhesion and migration (Kim et al. 2010).

Growth factors are other key molecules involved in maternal-conceptus signaling and conceptus development. Endometrial expression of fibroblast growth factor 7 (FGF7), TGFB1 and uterine lumen content of insulin-like growth factor 1 (IGF1) are elevated during peri-implantation period and may be regulated by estrogen and/or progesterone (for review see, Waclawik et al. (2009b); Fig. 2).

\section{Proinflammatory environment during the implantation period}

Implantation displays hallmark signs of inflammation (Jabbour et al. 2009). However, both pro- and antiinflammatory pathways are involved in establishment of the receptive endometrium and activation of them is tightly controlled. Overactivation of inflammatory pathways leads to the onset of reproductive disorders or diseases (Jabbour et al. 2009). For example, in pigs, highly localized and abundant expression of interferon $\gamma$ (IFNG), tumor necrosis factor $\alpha$ (TNF), and interleukin $1 \beta$ (IL1B) in the endometrium is associated with arrested conceptus development between days 15 and 23 of pregnancy (Tayade et al. 2007, Croy et al. 2009). Cytokines are involved in the proliferation, differentiation, and cell survival that play a role in conceptus growth and implantation. It seems that in pigs, as in other species, implantation and establishment of pregnancy is associated with upregulation of expression of inflammatory mediators, which include cytokines, growth

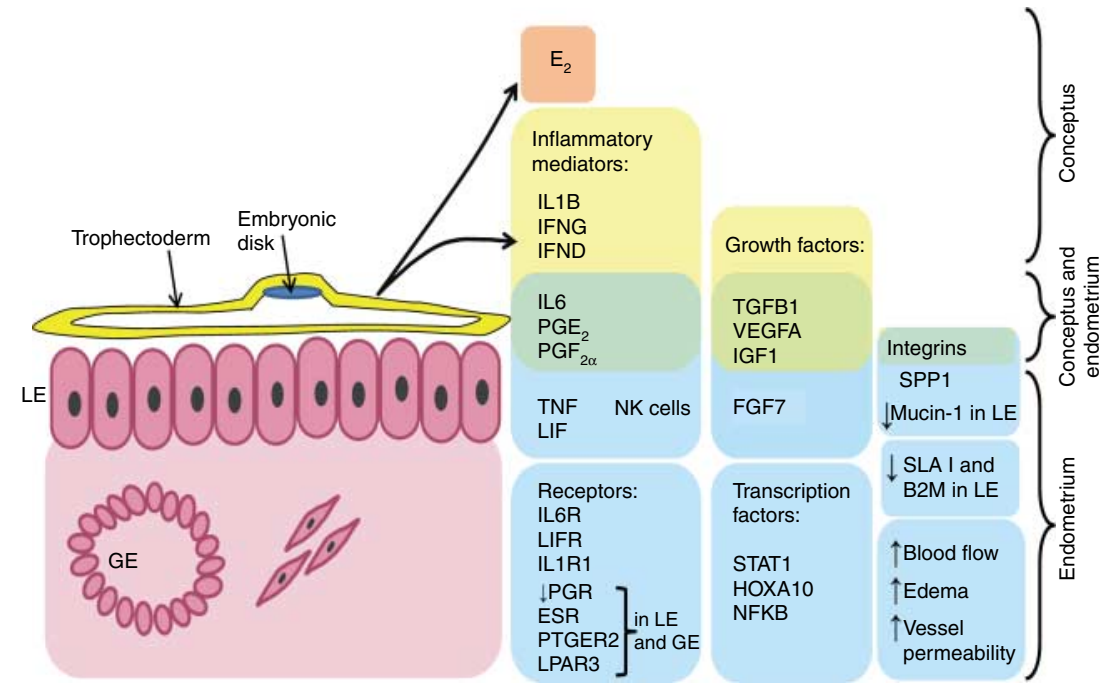

Figure 2 Establishment of pregnancy is dependent on various biological molecules produced by conceptus (indicated in orange and yellow boxes), the endometrium (indicated in blue boxes), and both endometrium and conceptus (green boxes). Many factors originating from porcine conceptus are inflammatory mediators: interferon $\gamma$ (IFNG) and interferon $\delta$ (IFND), interleukin $1 \beta$ (IL1B), IL6, and prostaglandin $E_{2}\left(\mathrm{PGE}_{2}\right)$ and PGF $\mathrm{P}_{2 \alpha}$ indicating that the embryo induces inflammatory pathways in the endometrium during the peri-implantation period. Endometrium responds to these embryonic signals by enhancing further, progesterone-induced uterine receptivity and establishment of proinflammatory environment during implantation. LE, uterine luminal epithelium; GE, uterine glandular epithelium; $E_{2}$, 17 $\beta$-estradiol; TNF, tumor necrosis factor $\alpha$; LIF, leukemia inhibitory factor; NK cells, natural killer cells; IL6R, receptor of interleukin 6; LIFR, receptor of leukemia inhibitory factor; IL1R1, interleukin 1 receptor type I; PGR, progesterone receptor; ESR, estrogen receptor; PTGER2, PGE 2 receptor; LPAR3, lysophosphatidic acid receptor; TGFB1, transforming growth factor $\beta$; VEGFA, vascular endothelial growth factor; IGF1, insulin-like growth factor 1; FGF7, fibroblast growth factor 7; HOXA10, Homeobox A10; NFKB, nuclear factor kappa B; SPP1, secreted phosphoprotein 1; SLA I, swine leukocyte antigens class I; B2M, $\beta 2$ microglobulin. 
factors, and lipid mediators. As in humans and mice, early porcine pregnancy is dominated by proinflammatory type I cytokines such as IFNG and TNF (Croy et al. 2009).

Before implantation and during the attachment period, the porcine conceptus produces various inflammatory mediators: IFNG and interferon $\delta$ (IFND; Joyce et al. 2007), IL1B (Ross et al. 2003), IL6 (Modrić et al. 2000), $\mathrm{PGE}_{2}$ and $\mathrm{PGF}_{2 \alpha}$ (Waclawik \& Ziecik 2007), indicating that the embryo induces inflammatory pathways in the endometrium (Fig. 2). Conceptus secreted IL1B stimulates endometrial expression of PTGS1 and PTGS2 mRNA, as well as tended to increase expression of IL1 receptor type I (IL1R1) in the endometrium (White et al. 2009). A microarray study revealed that the specific cytokine receptors IL6R, leukemia inhibitory factor receptor (LIFR), and IL11 receptor $\alpha(I L 11 R A)$ are significantly differentially expressed in the endometrium of pregnant pigs compared with nonpregnant animals (Østrup et al. 2010). Therefore, it is suggested that endometrial regulation of signaling in cytokines, particularly the IL6 family members, is to a great extent controlled by the expression of their specific receptors in the endometrium.

The endometrium responds to the embryonic signals during the implantation window by enhancing expression of genes involved in communications between the conceptus and uterus. IFND and IFNG exert an effect in the endometrium by cooperative induction of cytokinespecific transcription factors, such as STAT1 (Joyce et al. 2007). Interferon response genes, swine leukocyte antigens (MHC class I molecules in pigs; SLA) class I and $\beta 2$ microglobulin (B2M), which are involved in the discrimination of self from non-self by the immune system, are cell type-specifically regulated in the endometrium (Joyce et al. 2008). Downregulation of SLA class I and B2M expression in uterine LE and lack of expression of these genes in trophoblast (Ramsoondar et al. 1999), may be important for preventing fetal allograft rejection.

During early pregnancy the endometrium also produces another proinflammatory cytokine, LIF (Modrić et al. 2000). LIF is involved in controlling the uterine receptivity in other species and is essential for implantation in mice (Paria et al. 2002). Interestingly, content of LIF mRNA gradually increases in the porcine endometrium between days 10 and 15 of pregnancy (Blitek et al. 2010a). It needs to be determinated if estrogen of conceptus origin can stimulate LIF expression in the pig similarly as ovarian estrogen does in mice and other species. Another cytokine, expressed in the porcine endometrium during early pregnancy is TNF (Yu et al. 1998). The source of TNF may be macrophages, which are present in the endometrium during the estrous cycle and early pregnancy, as well as endometrial cells and conceptus (Hunt et al. 1996). Recent studies indicate that TNF stimulates $\mathrm{PGE}_{2}$ synthesis and secretion through upregulation of PTGS2 mRNA, as well as
mPGES-1 mRNA and protein content in porcine LE cells collected from gilts on days 11-12 after estrus (Waclawik et al. 2010).

Similarly to inflammation, vascular changes, increased uterine vascular permeability, and endometrial edema are observed during conceptus implantation in pigs (Keys et al. 1986, Laforest \& King 1992). Elevated vascular permeability and blood flow in the uterus are suggested to enhance transport of nutrients toward the conceptus and allow access of embryoinduced products to the maternal circulation (Keys et al. 1986). One important molecule that is involved in remodeling of endometrial vasculature is VEGFA. During the maternal recognition of pregnancy, both IGF1 and $\mathrm{PGE}_{2}$ stimulate VEGFA expression in stromal cells (Kaczmarek et al. 2008). In addition, the conceptus contributes to synthesis of VEGFA since its expression increases gradually until day 16 of pregnancy (Kaczmarek et al. 2009). Transcription profiles for endometrial lymphocytes indicate that lymphocytes contribute to and regulate angiogenesis through transcription of VEGFA, hypoxia inducible factor $1 \alpha$, and IFNG (Tayade et al. 2007). During implantation period, number of uterine natural killer (NK) cells increases in the porcine endometrium. These cells are scattered through the stroma, beneath $\mathrm{LE}$, around blood vessels, and uterine glands (Engelhardt et al. 2002). In contrast to the recruitment of NK cells in humans and mice, which is driven by decidual cells, porcine NK cells require conceptus-derived signals.

During the implantation period, PG synthesis pathway is altered in the endometrium and the conceptus (Waclawik et al. 2006, Waclawik \& Ziecik 2007). On days 16-21 of pregnancy, content of PGFS is upregulated in the endometrium (Waclawik et al. 2006). Similarly, content of mPGES-1 protein is increased in the endometrium on days 18-19 of pregnancy comparing with days 18-19 of the estrous cycle. In later stage of implantation and early placentation, a twofold upregulation of mPGES-1 protein expression is detected in the endometrium in the implantation sites compared with inter-implantation sites (Waclawik et al. 2009a). After initiation of implantation, expression of PTGS1, PGFS, and CBR1 mRNA rapidly increase in conceptus/ trophoblast (Waclawik \& Ziecik 2007).

\section{PG signaling during the implantation period}

The localization of $\mathrm{PGE}_{2}$ synthesis corresponds highly to expression of $\mathrm{PGE}_{2}$ receptor in the porcine endometrium (Waclawik et al. 2006, 2009a). PTGER2 protein is highly expressed in LE and GE and in uterine blood vessels, and moderately in myometrium. Endometrial expression of PTGER2 is greater during implantation and can be upregulated by estrogen and $\mathrm{PGE}_{2}$ itself (Waclawik et al. 2009a). 
Identification of the $\mathrm{PGE}_{2}$ receptors PTGER2 and PTGER4 in the porcine endometrium (Waclawik et al. 2009a) and in the conceptus (Waclawik et al. 2008b) indicates that $\mathrm{PGE}_{2}$ could act directly to promote uterine function, as well as conceptus development and migration in the uterus (Pope et al. 1982, Geisert et al. 1990, Giguère et al. 2000). $\mathrm{PGE}_{2}$ is implicated in the local increase in endometrial vascular permeability and preparation for angiogenesis and implantation (Hamilton \& Kennedy 1994, Kennedy et al. 2007). $\mathrm{PGE}_{2}$ could stimulate angiogenesis in the porcine endometrium through upregulating VEGFA synthesis and secretion by endometrial cells (Kaczmarek et al. 2008).

It is possible that PG species other than $\mathrm{PGE}_{2}$ and $\mathrm{PGF}_{2 \alpha}$ play an important role in the establishment of pregnancy. For example, in rodents and ruminants, prostacyclin is considered to be involved in implantation and signaling pathways between the uterus and the conceptus during peri-implantation period, respectively (Cammas et al. 2006, Kennedy et al. 2007, Ulbrich et al. 2009). However, in the pig, the role of prostacyclin in the early pregnancy still remains to be elucidated.

\section{Uterine receptivity markers involved in PG synthesis}

Lysophosphatidic acid (LPA) is a phospholipid-derived mediator increasing endometrial PTGS2 expression (Seo et al. 2008; Fig. 1). Content and type of LPA in the porcine uterine lumen differs between day 12 of the estrous cycle and pregnancy. LPA acts through specific G-protein coupled receptors LPAR1-LPAR4. Among them, LPAR3 is considered to be an uterine receptivity marker critical for embryo migration and spacing in mice (Ye et al. 2005). In women displaying recurrent implantation failure expression of LPAR3 is decreased (Achache et al. 2010). In the pig, endometrial LPAR3 expression is upregulated during early pregnancy with the highest levels on days 11-12 (Kaminska et al. 2008). $\angle P A R 3$ mRNA content is greater in the porcine endometrium from the gravid compared with the nongravid uterine horn in unilateral pregnancy (Kaminska et al. 2008). This receptor is localized to LE, GE, and the conceptus and its expression is stimulated by estrogen (Seo et al. 2008).

Another uterine receptivity marker linked to $P G$ synthesis pathway is homeobox A10 (HOXA10). Although the HOXA10 gene plays a role in uterine development, it is also expressed in adult uteri in many species, including pigs (Blitek et al. 2010a). In mice, targeted disruption of HOXA10 expression leads to implantation failure. This transcription factor may mediate steroid action in endometrial tissue and regulate PTGS2 expression and PG synthesis in murine uterus (Paria et al. 2002). Our recent studies indicate that both PTGS2 and HOXA10 genes may be simultaneously regulated by steroids in the porcine endometrium (Blitek et al. 2010b). Endometrial HOXA10 expression is stimulated by $\mathrm{E}_{2}$ (Blitek et al. 2010b) and its mRNA content is increased during implantation in the pig (Blitek et al. 2010a).

\section{Some new insights on PG synthesis during early pregnancy in other species}

Studying interactions of human endometrium and trophoblast during the peri-implantation period is difficult in vitro and impossible in vivo. Studies using stromal cells of the human endometrium decidualized with progesterone and treated with the conditioned media from trophoblasts indicated that human trophoblast signals the decidua, which in turn amplifies conceptus signals, especially related to immune modulation and angiogenesis, resulting in an enriched cytokine environment (Hess et al. 2007). Immune response is one of the most highly represented gene ontology categories of upregulated genes in response to trophoblast-secreted products in decidual stromal cells. In vitro models such as decidualized stromal cells treated with conditioned media from trophoblasts and an in vitro co-culture system of endometrial stromal cells with the first-trimester trophoblast explants revealed upregulation of mPGES-1 (PTGES) in human endometrial cells (Popovici et al. 2006, Hess et al. 2007). Moreover, a recent study showed that the human embryonic signal, chorionic gonadotropin, regulates the mPGES-1 promoter and induces mPGES-1 synthesis in endometrial epithelial cells via the PI3K-ERK1/2 pathway (Banerjee et al. 2009). Interestingly, in rats, mPGES-1 mRNA and protein were only detected in the subluminal stroma surrounding the implanting blastocyst at the implantation site on day 6 of pregnancy, but were not observed in the inter-implantation site on day 6 of pregnancy and on day 6 of pseudopregnancy (Cong et al. 2006). Thus, it is suggested that the presence of an active blastocyst is required for mPGES-1 expression at the implantation site in this species. The strong mPGES- 1 expression in the implantation site and decidual cells indicates that mPGES-1 play an important role during implantation and decidualization in mice ( $\mathrm{Ni}$ et al. 2002). Moreover, the conceptus signal in ruminants, IFNT, increases $\mathrm{PGE}_{2}$ secretion in epithelial cells of bovine endometrium (Asselin \& Fortier 2000) and in the ovine endometrium (Dorniak et al. 2011). IFNT increases endometrial PTGS activity and the amount of PGs in the ovine uterine lumen. When PG synthesis is inhibited, IFNT stimulation of many genes (FGF2, ISG15, RSAD2, CST3, CTSL, GRP, LGALS15, SLC2A1, SLC5A1, and SLC7A2) is reduced (Dorniak et al. 2011). Thus, PGs are suggested to be mediators of endometrial responses to progesterone and conceptus signal in the uterus, as well as being important regulators of ovine conceptus elongation. Although embryonic pregnancy recognition signals and type of placentation differ across species, it seems that the 
common mechanism occurring in early pregnancy is that the conceptus targets PG synthesis, especially $\mathrm{PGE}_{2}$ synthase mPGES-1 in the endometrium.

\section{Conclusions and future directions}

This review summarizes recognized signaling cascades and new research in mechanisms responsible for conceptus-endometrial interactions during the periimplantation period in the pig with comparison with other species. One of the most intriguing challenges in understanding mechanisms of pregnancy establishment is to establish a hierarchy and timing of molecular relationships during the maternal-conceptus crosstalk. The porcine conceptus signal, estrogen, may prevent luteal regression through modification of expression of the enzymes involved in PG synthesis, reducing endometrial release of $\mathrm{PGF}_{2 \alpha}$ and favoring $\mathrm{PGE}_{2}$ release on days $10-13$ of pregnancy. Conceptus $\mathrm{PGE}_{2}$ could be amplified by a $\mathrm{PGE}_{2}$ feedback loop in the endometrium. A balanced interplay among the enzymes and receptors of PGs inside the uterus during the early pregnancy is required to provide a suitable environment for the embryo, which first inhibits luteolysis to initiate the maternal recognition of pregnancy, and then proceed for implantation. It seems that in pigs, as in other species, implantation and establishment of pregnancy are associated with upregulation of expression of proinflammatory factors that include cytokines, growth factors, and lipid mediators. During the peri-implantation period, the porcine conceptus produces inflammatory mediators: IFNG, IFND, IL1B, IL6, and PGs, which probably activate inflammatory pathways in the endometrium. The endometrium responds to these embryonic signals by enhancing further progesteroneinduced uterine receptivity. In comparative studies, the pig may be a useful model for an initial step of implantation. This knowledge is required for translational research to increase reproductive efficiencies and reproductive health in humans and animals. The possibility of isolating specific key parameters in the endometrium may help to identify risk factors for implantation failure and, thus, hopefully lead to the development of treatments that would improve pregnancy rate.

\section{Declaration of interest}

The author declares that there is no conflict of interest that could be perceived as prejudicing the impartiality of this review.

\section{Funding}

Studies described in this manuscript are supported partially by the Polish Ministry for Science and Higher Education (grant number DWM/N106/COST/2008). A Waclawik was awarded the Domestic Grant for Young Scientists from the Foundation for Polish Sciences.

\section{References}

Achache H, Tsafrir A, Prus D, Reich R \& Revel A 2010 Defective endometrial prostaglandin synthesis identified in patients with repeated implantation failure undergoing in vitro fertilization. Fertility and Sterility 94 1271-1278. (doi:10.1016/j.fertnstert.2009.07.1668)

Akinlosotu BA, Diehl JR \& Gimenez T 1986 Sparing effects of intrauterine treatment with prostaglandin $\mathrm{E}_{2}$ on luteal function in cycling gilts. Prostaglandins 32 291-299. (doi:10.1016/0090-6980(86)90132-2)

Ashworth MD, Ross JW, Hu J, White FJ, Stein DR, Desilva U, Johnson GA, Spencer TE \& Geisert RD 2006 Expression of porcine endometrial prostaglandin synthase during the estrous cycle and early pregnancy, and following endocrine disruption of pregnancy. Biology of Reproduction 74 1007-1015. (doi:10.1095/biolreprod.105.046557)

Asselin E \& Fortier MA 2000 Detection and regulation of the messenger for a putative bovine endometrial 9-keto-prostaglandin $\mathrm{E}(2)$ reductase effect of oxytocin and interferon-tau. Biology of Reproduction 62 125-131. (doi:10.1095/biolreprod62.1.125)

Auletta FJ \& Flint AP 1988 Mechanisms controlling corpus luteum function in sheep, cows, nonhuman primates, and women especially in relation to the time of luteolysis. Endocrine Reviews 9 88-105. (doi:10.1210/edrv9-1-88)

Banerjee P, Sapru K, Strakova Z \& Fazleabas AT 2009 Chorionic gonadotropin regulates prostaglandin E synthase via a phosphatidylinositol 3-kinase-extracellular regulatory kinase pathway in a human endometrial epithelial cell line: implications for endometrial responses for embryo implantation. Endocrinology 150 4326-4337. (doi:10.1210/ en.2009-0394)

Bazer FW \& Thatcher WW 1977 Theory of maternal recognition of pregnancy in swine based on estrogen controlled endocrine versus exocrine secretion of prostaglandin $\mathrm{F}_{2 \alpha}$ by the uterine endometrium. Prostaglandins 14 397-400. (doi:10.1016/0090-6980(77)90185-X)

Bazer FW, Wu G, Spencer TE, Johnson GA, Burghardt RC \& Bayless K 2010 Novel pathways for implantation and establishment and maintenance of pregnancy in mammals. Molecular Human Reproduction 16 135-152. (doi:10.1093/molehr/gap095)

Blitek A, Kaczmarek MM, Kiewisz J \& Ziecik AJ 2010a Endometrial and conceptus expression of HoxA10, transforming growth factor beta1, leukemia inhibitory factor, and prostaglandin $\mathrm{H}$ synthase-2 in early pregnant pigs with gonadotropin-induced estrus. Domestic Animal Endocrinology 38 222-234. (doi:10.1016/j.domaniend.2009.11.001)

Blitek A, Kiewisz J, Waclawik A, Kaczmarek MM \& Ziecik AJ 2010 bffect of steroids on HOXA10 mRNA and protein expression and prostaglandin production in the porcine endometrium. Journal of Reproduction and Development 56 643-648. (doi:10.1262/jrd.10-046K)

Boiti C, Zerani M, Zampini D \& Gobbetti A 2000 Nitric oxide synthase activity and progesterone release by isolated corpora lutea of rabbits in the early and mid-luteal phases of pseudopregnancy are modulated differently by prostaglandin $E_{2}$ and prostaglandin $F_{2 \alpha}$ via adenylate cyclase and phospholipase C. Journal of Endocrinology 164 179-186. (doi:10.1677/joe.0.1640179)

Bowen JA, Bazer FW \& Burghardt RC 1996 Spatial and temporal analyses of integrin and Muc-1 expression in porcine uterine epithelium and trophectoderm in vivo. Biology of Reproduction 55 1098-1106. (doi:10. 1095/biolreprod55.5.1098)

Burghardt RC, Johnson GA, Jaeger LA, Ka H, Garlow JE, Spencer TE \& Bazer FW 2002 Integrins and extracellular matrix proteins at the maternal-fetal interface in domestic animals. Cells, Tissues, Organs 172 202-217. (doi:10.1159/000066969)

Cammas L, Reinaud P, Bordas N, Dubois O, Germain G \& Charpigny G 2006 Developmental regulation of prostacyclin synthase and prostacyclin receptors in the ovine uterus and conceptus during the peri-implantation period. Reproduction 131 917-927. (doi:10.1530/rep. 1.00799)

Christenson LK, Farley DB, Anderson LH \& Ford SP 1994 Luteal maintenance during early pregnancy in the pig: role for prostaglandin $E_{2}$. Prostaglandins 47 61-75. (doi:10.1016/0090-6980(94)90075-2)

Cong J, Diao HL, Zhao YC, Ni H, Yan YQ \& Yang ZM 2006 Differential expression and regulation of cylooxygenases, prostaglandin $\mathrm{E}$ synthases and prostacyclin synthase in rat uterus during the peri-implantation period. Reproduction 131 139-151. (doi:10.1530/rep.1.00861) 
Conley AJ \& Ford SP 1989 Direct luteotrophic effect of oestradiol-17 $\beta$ on pig corpora lutea. Journal of Reproduction and Fertility 87 125-131. (doi:10.1530/jrf.0.0870125)

Croy BA, Wessels JM, Linton NF, van den Heuvel M, Edwards AK \& Tayade C 2009 Cellular and molecular events in early and mid gestation porcine implantation sites: a review. In Control of Pig Reproduction VIII, pp 233-244. Eds H Rodriguez-Martinez, JL Vallet\& AJ Ziecik. Nottingham: Nottingham University Press.

Dorniak P, Bazer FW \& Spencer TE 2011 Prostaglandins regulate conceptus elongation and mediate effects of interferon tau on the ovine uterine endometrium. Biology of Reproduction 84 1119-1127. (doi:10.1095/ biolreprod.110.089979)

Engelhardt H, Croy BA \& King GJ 2002 Evaluation of natural killer cell recruitment to embryonic attachment sites during early porcine pregnancy. Biology of Reproduction 66 1185-1192. (doi:10.1095/ biolreprod66.4.1185)

Erdem H \& Guzeloglu A 2010 Effect of meloxicam treatment during early pregnancy in Holstein heifers. Reproduction in Domestic Animals 45 625-628. (doi:10.1111/j.1439-0531.2008.01317.x)

Erikson DW, Burghardt RC, Bayless KJ \& Johnson GA 2009 Secreted phosphoprotein 1 (SPP1, osteopontin) binds to integrin alpha v beta 6 on porcine trophectoderm cells and integrin alpha $v$ beta 3 on uterine luminal epithelial cells, and promotes trophectoderm cell adhesion and migration. Biology of Reproduction 81 814-825. (doi:10.1095/biolreprod.109.078600)

Ferrell AD, Malayer JR, Carraway KL \& Geisert RD 2003 Sialomucin complex (Muc4) expression in porcine endometrium during the oestrous cycle and early pregnancy. Reproduction in Domestic Animals 38 63-65. (doi:10.1046/j.1439-0531.2003.00405.x)

Fitz TA, Hoyer PB \& Niswender GD 1984 Interactions of prostaglandins with subpopulations of ovine luteal cells. I. Stimulatory effects of prostaglandins $\mathrm{E}_{1}, \mathrm{E}_{2}$ and $\mathrm{I}_{2}$. Prostaglandins 28 119-126. (doi:10.1016/ 0090-6980(84)90119-9)

Flood PF 1974 Steroid-metabolizing enzymes in the early pig conceptus and in the related endometrium. Journal of Endocrinology 63 413-414. (doi:10.1677/joe.0.0630413)

Ford SP, Magness RR, Farley DB \& Van Orden DE 1982 Local and systemic effects of intrauterine estradiol-17 beta on luteal function of nonpregnant sows. Journal of Animal Science 55 657-664.

Gadsby JE, Lovdal JA, Britt JH \& Fitz TA 1993 Prostaglandin F $_{2 \alpha}$ receptor concentrations in corpora lutea of cycling, pregnant, and pseudopregnant pigs. Biology of Reproduction 49 604-608. (doi:10.1095/ biolreprod49.3.604)

Garverick HA, Polge C \& Flint AP 1982 Oestradiol administration raises luteal $\mathrm{LH}$ receptor levels in intact and hysterectomized pigs. Journal of Reproduction and Fertility 66 371-377. (doi:10.1530/jrf.0.0660371)

Geisert RD, Rasby RJ, Minton JE \& Wetteman RP 1986 Role of prostaglandins in development of porcine blastocysts. Prostaglandins 31 191-204. (doi:10.1016/0090-6980(86)90046-8)

Geisert RD, Zavy MT, Moffatt RJ, Blair RM \& Yellin T 1990 Embryonic steroids and the establishment of pregnancy in pigs. Journal of Reproduction and Fertility. Supplement 40 293-305.

Geisert RD, Brenner RM, Moffatt J, Harney JP, Yellin T \& Bazer FW 1993 Changes in oestrogen receptor protein, mRNA expression and localization in the endometrium of cyclic and pregnant gilts. Reproduction, Fertility, and Development 5 247-260. (doi:10.1071/RD9930247)

Geisert RD, Ross JW, Ahworth MD, White FJ, Johnson GA \& DeSilva U 2006 Maternal recognition of pregnancy signal or endocrine disruptor: the two faces of oestrogen during establishment of pregnancy in the pig. In Control of Pig Reproduction VII, pp 131-145. Eds C) Ashworth\& RR Kraeling. Nottingham: Nottingham University Press.

Giguère A, Girard CL, Lambert R, Laforest JP \& Matte JJ 2000 Reproductive performance and uterine prostaglandin secretion in gilts conditioned with dead semen and receiving dietary supplements of folic acid. Canadian Journal of Animal Science 80 467-472. (doi:10.4141/A99107)

Gregoraszczuk EL \& Michas N 1999 Progesterone and estradiol secretion by porcine luteal cells is influenced by individual and combined treatment with prostaglandins $E_{2}$ and $F_{2 \alpha}$ throughout the estrus cycle. Prostaglandins \& Other Lipid Mediators 57 231-241. (doi:10.1016/ S0090-6980(99)00009-X)
Hahlin M, Dennefors B, Johanson C \& Hamberge L 1988 Luteotropic effects of prostaglandin $E_{2}$ on the human corpus luteum of the menstrual cycle and early pregnancy. Journal of Clinical Endocrinology and Metabolism 66 909-914. (doi:10.1210/jcem-66-5-909)

Hamilton GS \& Kennedy TG 1994 Uterine vascular changes after unilateral intrauterine infusion of indomethacin and prostaglandin $E_{2}$ to rats sensitized for the decidual cell reaction. Biology of Reproduction $\mathbf{5 0}$ 757-764. (doi:10.1095/biolreprod50.4.757)

Harris TE, Squires PE, Michael AE, Bernal AL \& Abayasekara DR 2001 Human granulosa-lutein cells express functional EP1 and EP2 prostaglandin receptors. Biochemical and Biophysical Research Communications 285 1089-1094. (doi:10.1006/bbrc.2001.5301)

Hess AP, Hamilton AE, Talbi S, Dosiou C, Nyegaard M, Nayak N, Genbecev-Krtolica O, Mavrogianis P, Ferrer K, Kruessel J et al. 2007 Decidual stromal cell response to paracrine signals from the trophoblast: amplification of immune and angiogenic modulators. Biology of Reproduction 76 102-117. (doi:10.1095/biolreprod.106.054791)

Hunt JS, Chen HL \& Miller L 1996 Tumor necrosis factors: pivotal components of pregnancy? Biology of Reproduction 54 554-562. (doi:10.1095/biolreprod54.3.554)

Hunter RH \& Poyser NL 1982 Uterine secretion of prostaglandin $F_{2 \alpha}$ in anaesthetized pigs during the oestrous cycle and early pregnancy. Reproduction, Nutrition, Development 22 1013-1023. (doi:10.1051/ rnd:19820712)

Jabbour HN, Milne SA, Williams AR, Anderson RA \& Boddy SC 2001 Expression of COX-2 and PGE synthase and synthesis of $\operatorname{PGE}(2)$ in endometrial adenocarcinoma: a possible autocrine/paracrine regulation of neoplastic cell function via EP2/EP4 receptors. British Journal of Cancer 85 1023-1031. (doi:10.1054/bjoc.2001.2033)

Jabbour HN, Sales KJ, Catalano RD \& Norman JE 2009 Inflammatory pathways in female reproductive health and disease. Reproduction 138 903-919. (doi:10.1530/REP-09-0247)

Jaeger LA, Spiegel AK, Ing NH, Johnson GA, Bazer FW \& Burghardt RC 2005 Functional effects of transforming growth factor beta on adhesive properties of porcine trophectoderm. Endocrinology 146 3933-3942. (doi:10.1210/en.2005-0090)

Jenkin G 1992 Interaction between oxytocin and prostaglandin $F_{2 \alpha}$ during luteal regression and early pregnancy in sheep. Reproduction, Fertility, and Development 4 321-328. (doi:10.1071/RD9920321)

Johnson GA, Bazer FW, Burghardt RC, Spencer TE, Wu G \& Bayless KJ 2009 Conceptus-uterus interactions in pigs: endometrial gene expression in response to estrogens and interferons from conceptuses. In Control of Pig Reproduction VIII, pp 321-332. Eds H RodriguezMartinez, JL Vallet\& AJ Ziecik. Nottingham: Nottingham University Press.

Joyce MM, Burghardt RC, Geisert RD, Burghardt JR, Hooper RN, Ross JW, Ashworth MD \& Johnson GA 2007 Pig conceptuses secrete estrogen and interferons to differentially regulate uterine STAT1 in a temporal and cell type-specific manner. Endocrinology 148 4420-4431. (doi:10.1210/en. 2007-0505)

Joyce MM, Burghardt JR, Burghardt RC, Hooper RN, Bazer FW \& Johnson GA 2008 Uterine MHC class I molecules and beta 2-microglobulin are regulated by progesterone and conceptus interferons during pig pregnancy. Journal of Immunology 181 2494-2505.

Ka H, Al-Ramadan S, Erikson DW, Johnson GA, Burghardt RC, Spencer TE, Jaeger LA \& Bazer FW 2007 Regulation of expression of fibroblast growth factor 7 in the pig uterus by progesterone and estradiol. Biology of Reproduction 77 172-180. (doi:10.1095/biolreprod.106.056309)

Kaczmarek MM, Blitek A, Kaminska K, Bodek G, Zygmunt M, Schams D \& Ziecik AJ 2008 Assessment of VEGF-receptor system expression in the porcine endometrial stromal cells in response to insulin-like growth factor-I, relaxin, oxytocin and prostaglandin $\mathrm{E}_{2}$. Molecular and Cellular Endocrinology 291 33-41. (doi:10.1016/j.mce.2008.04.020)

Kaczmarek MM, Kiewisz J, Schams D \& Ziecik AJ 2009 Expression of VEGF-receptor system in conceptus during peri-implantation period and endometrial and luteal expression of soluble VEGFR-1 in the pig. Theriogenology 71 1298-1306. (doi:10.1016/j.theriogenology.2008.12.022)

Kaminska K, Wasielak M, Bogacka I, Blitek M \& Bogacki M 2008 Quantitative expression of lysophosphatidic acid receptor 3 gene in porcine endometrium during the periimplantation period and estrous cycle. Prostaglandins \& Other Lipid Mediators 85 26-32. (doi:10.1016/j. prostaglandins.2007.10.001) 
Kennedy TG, Gillio-Meina C \& Phang SH 2007 Prostaglandins and the initiation of blastocyst implantation and decidualization. Reproduction 134 635-643. (doi:10.1530/REP-07-0328)

Keys JL, King GJ \& Kennedy TG 1986 Increased uterine vascular permeability at the time of embryonic attachment in the pig. Biology of Reproduction 34 405-411. (doi:10.1095/biolreprod34.2.405)

Kim J, Erikson DW, Burghardt RC, Spencer TE, Wu G, Bayless KJ, Johnson GA \& Bazer FW 2010 Secreted phosphoprotein 1 binds integrins to initiate multiple cell signaling pathways, including FRAP1/mTOR, to support attachment and force-generated migration of trophectoderm cells. Matrix Biology 29 369-382. (doi:10.1016/j.matbio. 2010.04.001)

Kotwica G, Franczak A, Okrasa S \& Kotwica J 1999 Effect of an oxytocin antagonist on prostaglandin $\mathrm{F}_{2 \alpha}$ secretion and the course of luteolysis in sows. Acta Veterinaria Hungarica 4 249-262.

Kowalczyk AE, Kaczmarek MM, Schams D \& Ziecik AJ 2008 Effect of prostaglandin $E_{2}$ and tumor necrosis factor $\alpha$ on the VEGF-receptor system expression in cultured porcine luteal cells. Molecular Reproduction and Development 75 1558-1566. (doi:10.1002/mrd.20897)

Kowalski AA, Graddy LG, Vale-Cruz DS, Choi I, Katzenellenbogen BS, Simmen FA \& Simmen RC 2002 Molecular cloning of porcine estrogen receptor-beta complementary DNAs and developmental expression in periimplantation embryos. Biology of Reproduction 66 760-769. (doi:10.1095/biolreprod66.3.760)

Kraeling RR, Rampacek GB \& Fiorello NA 1985 Inhibition of pregnancy with indomethacin in mature gilts and prepuberal gilts induced to ovulate. Biology of Reproduction 32 105-110. (doi:10.1095/biolreprod32.1.105)

Krzymowski T \& Stefanczyk-Krzymowska S 2004 The oestrous cycle and early pregnancy - a new concept of local endocrine regulation. Veterinary Journal 168 285-296. (doi:10.1016/j.tvjl.2003.10.010)

Laforest JP \& King GJ 1992 Structural and functional aspects of porcine endometrial capillaries on days 13 and 15 after oestrus or mating. Journal of Reproduction and Fertility 94 269-277. (doi:10.1530/jrf.0. 0940269)

Mathew DJ, Sellner EM, Green JC, Okamura CS, Anderson LL, Lucy MC \& Geisert RD 2011 Uterine progesterone receptor expression, conceptus development, and ovarian function in pigs treated with RU 486 during early pregnancy. Biology of Reproduction 84 130-139. (doi:10.1095/ biolreprod.110.086843)

McCracken JA, Custer EE \& Lamsa JC 1999 Luteolysis: a neuroendocrinemediated event. Physiological Reviews 79 263-323.

McNeer RR, Carraway CA, Fregien NL \& Carraway KL 1998 Characterization of the expression and steroid hormone control of sialomucin complex in the rat uterus: implications for uterine receptivity. Journal of Cellular Physiology 176 110-119. (doi:10.1002/(SICI)1097-4652(199807)176:1 $<110$ ::AID-JCP13>3.0.CO;2-B)

Mirando MA, Prince BC, Tysseling KA, Carnahan KG, Ludwig TE, Hoagland TA \& Crain RC 1995 A proposed role for oxytocin in regulation of endometrial prostaglandin $\mathrm{F}_{2 \alpha}$ secretion during luteolysis in swine. Advances in Experimental Medicine and Biology 395 421-433.

Modrić T, Kowalski AA, Green ML, Simmen RC \& Simmen FA 2000 Pregnancy-dependent expression of leukaemia inhibitory factor (LIF), LIF receptor-beta and interleukin-6 (IL-6) messenger ribonucleic acids in the porcine female reproductive tract. Placenta 21 345-353. (doi:10.1053/ plac.1999.0493)

Moeljono MP, Thatcher WW, Bazer FW, Frank M, Owens LJ \& Wilcox CJ 1977 A study of prostaglandin $F_{2 \alpha}$ as the luteolysin in swine: II. Characterization and comparison of prostaglandin $F$, estrogens and progestin concentrations in utero-ovarian vein plasma of nonpregnant and pregnant gilts. Prostaglandins 14 543-555. (doi:10.1016/00906980(77)90268-4)

Ni H, Sun T, Ding NZ, Ma XH \& Yang ZM 2002 Differential expression of microsomal prostaglandin $\mathrm{E}$ synthase at implantation sites and in decidual cells of mouse uterus. Biology of Reproduction 67 351-358. (doi:10.1095/biolreprod67.1.351)

Østrup E, Bauersachs S, Blum H, Wolf E \& Hyttel P 2010 Differential endometrial gene expression in pregnant and nonpregnant sows. Biology of Reproduction 83 277-285. (doi:10.1095/biolreprod.109.082321)

Paria BC, Reese J, Das SK \& Dey SK 2002 Deciphering the cross-talk of implantation: advances and challenges. Science 296 2185-2188. (doi:10.1126/science.1071601)
Pope WF, Maurer RR \& Stormshak F 1982 Intrauterine migration of the porcine embryo-interaction of embryo, uterine flushings and indomethacin on myometrial function in vitro. Journal of Animal Science $\mathbf{5 5}$ 1169-1178.

Popovici RM, Betzler NK, Krause MS, Luo M, Jauckus J, Germeyer A, Bloethner S, Schlotterer A, Kumar R, Strowitzki T et al. 2006 Gene expression profiling of human endometrial-trophoblast interaction in a coculture model. Endocrinology 147 5662-5675. (doi:10.1210/en. 2006-0916)

Ramsoondar JJ, Christopherson RJ, Guilbert LJ, Dixon WT, Ghahary A, Ellis S, Wegmann TG \& Piedrahita JA 1999 Lack of class I major histocompatibility antigens on trophoblast of periimplantation blastocysts and term placenta in the pig. Biology of Reproduction $60387-397$. (doi:10.1095/biolreprod60.2.387)

Ross JW, Malayer JR, Ritchey JW \& Geisert RD 2003 Characterization of the interleukin-1beta system during porcine trophoblastic elongation and early placental attachment. Biology of Reproduction 69 1251-1259. (doi:10.1095/biolreprod.103.015842)

Ross JW, Ashworth MD, Stein DR, Couture OP, Tuggle CK \& Geisert RD 2009 Identification of differential gene expression during porcine conceptus rapid trophoblastic elongation and attachment to uterine luminal epithelium. Physiological Genomics 36 140-148. (doi:10.1152/ physiolgenomics.00022.2008)

Ross JW, Ashworth MD, Mathew D, Reagan P, Ritchey JW, Hayashi K, Spencer TE, Lucy M \& Geisert RD 2010 Activation of the transcription factor, nuclear factor kappa-B, during the estrous cycle and early pregnancy in the pig. Reproductive Biology and Endocrinology 839. (doi:10.1186/1477-7827-8-39)

Sales KJ, Katz AA, Davis M, Hinz S, Soeters RP, Hofmeyr MD, Millar RP \& Jabbour HN 2001 Cyclooxygenase-2 expression and prostaglandin $\mathrm{E}(2)$ synthesis are up-regulated in carcinomas of the cervix: a possible autocrine/paracrine regulation of neoplastic cell function via EP2/EP4 receptors. Journal of Clinical Endocrinology and Metabolism 86 2243-2249. (doi:10.1210/jc.86.5.2243)

Sales KJ, List T, Boddy SC, Williams AR, Anderson RA, Naor Z \& Jabbour HN 2005 A novel angiogenic role for prostaglandin $F_{2 \alpha}-\mathrm{FP}$ receptor interaction in human endometrial adenocarcinomas. Cancer Research 65 7707-7716. (doi:10.1158/0008-5472.CAN-05-0101)

Sample GL, Kubotsu SL, Carnahan KG \& Mirando MA 2000 Interestrous interval of cyclic gilts is decreased by systemic but not intrauterine administration of exogenous oxytocin. Journal of Animal Science $\mathbf{7 8}$ 2393-2398.

Sample GL, Blackwell DM, Kubotsu SL \& Mirando MA 2004 Endocrine secretion of prostaglandin $\mathrm{F}_{2 \alpha}$ in cyclic gilts is decreased by intrauterine administration of exogenous oxytocin. Animal Reproduction Science 84 395-406. (doi:10.1016/j.anireprosci.2004.02.006)

Seo H, Kim M, Choi Y, Lee CK \& Ka H 2008 Analysis of lysophosphatidic acid (LPA) receptor and LPA-induced endometrial prostaglandin-endoperoxide synthase 2 expression in the porcine uterus. Endocrinology 149 6166-6175. (doi:10.1210/en.2008-0354)

Stefanczyk-Krzymowska S, Wasowska B, Chłopek J, Gilun P, Grzegorzewski W \& Radomski M 2006 Retrograde and local destination transfer of uterine prostaglandin $\mathrm{E}_{2}$ in early pregnant sow and its physiological consequences. Prostaglandins \& Other Lipid Mediators 81 71-79. (doi:10.1016/j.prostaglandins.2006.07.004)

Tayade C, Fang Y, Hilchie D \& Croy BA 2007 Lymphocyte contributions to altered endometrial angiogenesis during early and midgestation fetal loss. Journal of Leukocyte Biology 82 877-886. (doi:10.1189/jlb. 0507330)

Ulbrich SE, Schulke K, Groebner AE, Reichenbach HD, Angioni C, Geisslinger G \& Meyer HH 2009 Quantitative characterization of prostaglandins in the uterus of early pregnant cattle. Reproduction 138 371-382. (doi:10.1530/REP-09-0081)

Vallet JL, Christenson RK, Trout WE \& Klemcke HG 1998 Conceptus, progesterone, and breed effects on uterine protein secretion in swine. Journal of Animal Science 76 2657-2670.

Waclawik A \& Ziecik AJ 2007 Differential expression of prostaglandin (PG) synthesis enzymes in conceptus during peri-implantation period and endometrial expression of carbonyl reductase/PG 9-ketoreductase in the pig. Journal of Endocrinology 194 499-510. (doi:10.1677/JOE-07-0155)

Waclawik A, Rivero-Muller A, Blitek A, Kaczmarek MM, Brokken LJ, Watanabe K, Rahman NA \& Ziecik AJ 2006 Molecular cloning and 
spatiotemporal expression of prostaglandin $\mathrm{F}$ synthase and microsomal prostaglandin E synthase-1 in porcine endometrium. Endocrinology 147 210-221. (doi:10.1210/en.2005-0880)

Waclawik A, Kaczmarek MM, Kowalczyk AE, Bogacki M \& Ziecik AJ 2008a Expression of prostaglandin synthesis pathway enzymes in the porcine corpus luteum during the estrous cycle and early pregnancy. Theriogenology 70 145-152. (doi:10.1016/j.theriogenology.2008.03.008)

Waclawik A, Blitek A, Jabbour HN \& Ziecik AJ 2008b The expression and regulation of EP2 and EP4 in the pig endometrium. In Proceedings of the Society for Reproduction and Fertility 2008 Conference, Edinburgh, UK. Abstract P25, p 56.

Waclawik A, Jabbour HN, Blitek A \& Ziecik AJ 2009a Estradiol-17beta, prostaglandin $\mathrm{E}_{2}\left(\mathrm{PGE}_{2}\right)$, and the $\mathrm{PGE}_{2}$ receptor are involved in $\mathrm{PGE}_{2}$ positive feedback loop in the porcine endometrium. Endocrinology $\mathbf{1 5 0}$ 3823-3832. (doi:10.1210/en.2008-1499)

Waclawik A, Blitek A, Kaczmarek MM, Kiewisz J \& Ziecik AJ 2009b Antiluteolytic mechanisms and the establishment of pregnancy in the pig. In Control of Pig Reproduction VIII, pp 307-320. Eds H RodriguezMartinez, JL Vallet \& AJ Ziecik. Nottingham: Nottingham University Press.

Waclawik A, Blitek A \& Ziecik AJ 2010 Oxytocin and tumor necrosis factor alpha stimulate expression of prostaglandin $E_{2}$ synthase and secretion of prostaglandin $E_{2}$ by luminal epithelial cells of the porcine endometrium during early pregnancy. Reproduction 140 613-622. (doi:10.1530/REP10-0092)

Wasielak M, Glowacz M, Kaminska K, Waclawik A \& Bogacki M 2008 The influence of embryo presence on prostaglandin synthesis and prostaglandin $E_{2}$ and $F_{2 \alpha}$ content in corpora lutea during periimplantation period in the pig. Molecular Reproduction and Development $\mathbf{7 5}$ 1208-1216. (doi:10.1002/mrd.20862)

Watanabe K 2002 Prostaglandin F synthase. Prostaglandins \& Other Lipid Mediators 68-69 401-407. (doi:10.1016/S0090-6980(02)00044-8)

Weems YS, Lammoglia MA, Lewis AW, Randel RD, Sasser RG, Morita I \& Weems CW $1999 \mathrm{PGE}_{2}$ induces its own secretion in vitro by bovine 270day placenta but not by 200-day placenta. Prostaglandins \& Other Lipid Mediators 57 189-205. (doi:10.1016/S0090-6980(99)00003-9)
Weems CW, Weems YS \& Randel RD 2006 Prostaglandins and reproduction in female farm animals. Veterinary Journal 171 206-228. (doi:10.1016/j.tvjl.2004.11.014)

White FJ, Ross JW, Joyce MM, Geisert RD, Burghardt RC \& Johnson GA 2005 Steroid regulation of cell specific secreted phosphoprotein 1 (osteopontin) expression in the pregnant porcine uterus. Biology of Reproduction 73 1294-1301. (doi:10.1095/biolreprod.105.045153)

White FJ, Kimball EM, Wyman G, Stein DR, Ross JW, Ashworth MD \& Geisert RD 2009 Estrogen and interleukin-1 beta regulation of trophinin, osteopontin, cyclooxygenase-1, cyclooxygenase-2, and interleukin1 beta system in the porcine uterus. In Control of Pig Reproduction VIII, pp 203-204. Eds H Rodriguez-Martinez, JL Vallet \& AJ Ziecik. Nottingham: Nottingham University Press.

Ye X, Hama K, Contos JJ, Anliker B, Inoue A, Skinner MK, Suzuki H, Amano T, Kennedy G, Arai H et al. 2005 LPA3-mediated lysophosphatidic acid signalling in embryo implantation and spacing. Nature 435 104-108. (doi:10.1038/nature03505)

Yu Z, Gordon JR, Kendall J \& Thacker PA 1998 Elevation in tumour necrosis factor-alpha (TNF-alpha) messenger RNA levels in the uterus of pregnant gilts after oestrogen treatment. Animal Reproduction Science 50 57-67. (doi:10.1016/S0378-4320(97)00081-X)

Zavy MT, Bazer FW, Thatcher WW \& Wilcox CJ 1980 A study of prostaglandin $F_{2 \alpha}$ as the luteolysin in swine: V. Comparison of prostaglandin $F$, progestins, estrone and estradiol in uterine flushings from pregnant and nonpregnant gilts. Prostaglandins 20 837-851. (doi:10.1016/0090-6980(80)90137-9)

Zorrilla LM, Irvin MS \& Gadsby JE 2009 Protein kinase C isoforms in the porcine corpus luteum: temporal and spatial expression patterns. Domestic Animal Endocrinology 36 173-185. (doi:10.1016/j.domaniend.2008.10.008)

Received 9 February 2010

First decision 31 March 2010

Revised manuscript received 30 May 2011

Accepted 15 June 2011 